\title{
Formability of in-situ Austempered Transformation-induced Plasticity Steels After Laser Beam Welding
}

\author{
Vagner Braga ${ }^{1}$, Raquel Alvim de Figueiredo Mansur ${ }^{1}$, Rafael Humberto Mota de Siqueira ${ }^{1}$, Milton Sergio Fernandes de Lima ${ }^{1}$ \\ 1 Instituto de Estudos Avançados - IEAv, São José dos Campos, SP, Brasil.
}

Recebido: 17 Jul., 2018

Aceito: 08 Nov., 2018

E-mail: milton@ieav.cta.br (MSFL)
This is an Open Access article distributed under the terms of the Creative Commons Attribution Non-Commercial License which permits unrestricted non-commercial use, distribution, and reproduction in any medium provided the original work is properly cited.
Abstract: Laser welded Transformation-induced plasticity (TRIP) steels are known to generate martensite in the fusion (FZ) and the heat-affected (HAZ) zones. To solve this issue, the present study proposes a high temperature $(\mathrm{HT})$ welding to avoid decay below the martensite start temperature after laser welding. Therefore, an inductive heating has been used to reach $500{ }^{\circ} \mathrm{C}$ before laser weld of superposed $1.6 \mathrm{~mm}$ thick TRIP steel class 750 . After welding the temperature was kept constant at $500{ }^{\circ} \mathrm{C}$ for more 10 minutes in order to austemper. The microstructures of the welds at high temperature are composed of bainite and residual austenite with an FZ hardness up to $300 \mathrm{HV}$, compared to $450 \mathrm{HV}$ of the ambient temperature (AT) weld. The HT values of hardness are slightly higher than a traditional post-weld heat treatment (TW), $300 \mathrm{HV}$ compared to $250 \mathrm{HV}$, because of the tempering kinetics in each case. Erichsen cup indentation tests shown the HT coupons presents better formability compared to the AT or TW conditions. The present contribution highlights a possible solution to the intrinsic brittleness during cold forming of laser welded TRIP 750 steel by applying an inductive in-situ austempering.

Key-words: Laser welding; Transformation-induced plasticity steels; Post-welding heat treatments.

\section{Conformabilidade de Aços com Plasticidade Induzida por Deformação Após a Solda a Laser Seguida de Austêmpera in-situ}

Resumo: A solda a laser de aços com plasticidade induzida por transformação (TRIP) são conhecidos por gerar martensita nas zonas de fusão (ZF) e afetadas pelo calor (ZAC). Para resolver este problema, o presente estudo propõe uma soldagem em alta temperatura (HT) para evitar a transformação abaixo da temperatura inicial de martensita após a soldagem a laser. Assim, um aquecimento indutivo foi usado para atingir $500^{\circ} \mathrm{C}$ antes da solda a laser da classe 750 de aço TRIP sobreposto de 1,6 mm de espessura. Após a soldagem, a temperatura foi mantida constante a $500{ }^{\circ} \mathrm{C}$ por mais 10 minutos para austemperar. As microestruturas das soldas em alta temperatura são compostas por bainita e austenita residual com dureza na ZF de até $300 \mathrm{HV}$, contra $450 \mathrm{HV}$ da solda em temperatura ambiente (AT). Os valores da dureza HT são ligeiramente superiores ao tratamento térmico tradicional pós-soldagem (TW), 300 HV em comparação com 250 HV, devido à cinética de têmpera em cada caso. Os testes de embutimento Erichsen mostraram que as amostras HT apresentam melhor conformabilidade em comparação com as condições AT ou TW. A presente contribuição destaca uma possível solução para a fragilidade intrínseca durante a conformação a frio do aço TRIP 750 soldados a laser através da aplicação de uma austempera indutiva in situ.

Palavras-chave: Soldagem a laser; Aços de plasticidade induzida por transformação; Tratamentos térmicos pós-soldagem.

\section{Introduction}

Transformation-induced plasticity (TRIP) steels are usually manufactured in two steps. The first one requires a hot rolling at temperatures around $850^{\circ} \mathrm{C}$ to partially transform the primary austenite to ferrite. In a second step, the rolled product, usually as a coil, is placed in a furnace at temperatures around $400{ }^{\circ} \mathrm{C}$ growing bainite from the retained austenite. This well balanced microstructure is responsible for the excellent toughness of the steel and, in particular, for the continuous transformation of retained austenite to martensite during plastic deformation. This characteristic is interesting for rapid energy absorption in parts such as the cars security cell. Although laser beam welding is the preferable joining technique for the automotive structures, it presents a weakness. The rapid cooling of the 
fusion (FZ) and heat-affected (HAZ) zones creates an almost fully martensitic structure, responsible for an intrinsic brittleness and stress concentrator near to the fusion line of the blanks.

Tailored blanks for automotive components were usually produced by assembly two or more steel sheets by means of laser beam welding and die forming [1]. A metallurgical issue of the laser welded blanks remains on the brittleness of the fusion zone (FZ) and heat-affected zone (HAZ) of the advanced high strength steels (AHSS). The rapid cooling inherent to the laser weld produces an almost $100 \%$ martensite microconstituent in the grains, which may break during mechanical working.

Mujica et al. [2,3] and López Cortéz et al. [4] reported martensite formation in FZ and HAZ of Transformation Plasticity (TRIP) steels after laser welding. The hardness typically attains $500 \mathrm{HV}$ in these cases, thus rendering the weldment very brittle for post-processing. Correard et al. [5] showed that, under very controlled conditions, it is possible to generate bainitic grains in the FZ of dual phase (DP) steel, but in the TRIP case always a quantity of martensite appears. Bainite is always desirable in the place of martensite for blanks because of the good toughness and formability [6].

Lima et al. [7] proposed a method for high-temperature laser welding applicable to the $22 \mathrm{MnB5}$ steel. According to the authors, the welds produced at $455^{\circ} \mathrm{C}$ per 10 minutes presented $66 \%$ of bainite in an austenite matrix with consequent reduction in FZ hardness and increased toughness compared to the ambient temperature weld. As both bainite and residual austenite have an important role in TRIP steels mechanical behavior, it could be interesting to apply high temperature during the weld of these alloys as well.

The current paper proposes an in-situ austempering treatment subsequent to the laser welding of TRIP 750 steels by using an inductive furnace in the laser workstation. The aim is to produce bainite instead of martensite in the FZ grains. For comparison purposes, a standard procedure of annealing after the weld is also presented. As one of more stringent requirements for the welded blanks is to resist to severe plastic deformation during conformation [8], the current work access the formability obtained after instrumented Erichsen tests.

\section{Material and Methodology}

Transformation Plasticity (TRIP) steel blanks, class 750, were furnished in as-annealed condition in the form of $1.6 \mathrm{~mm}$ thick sheets. The chemical composition of the base steel is presented in Table 1.

Table 1. Composition of the TRIP steel in wt.\%. Fe and other minor elements are the balance.

\begin{tabular}{cccccccccc}
\hline $\mathbf{C}$ & $\mathbf{S i}$ & $\mathbf{M n}$ & $\mathbf{A l}$ & $\mathbf{N}$ & $\mathbf{P}$ & $\mathbf{S}$ & $\mathbf{C u}$ & $\mathbf{N i}$ & $\mathbf{C r}$ \\
0.22 & 1.36 & 1.49 & 0.044 & 0.004 & 0.021 & 0,0013 & 0.005 & 0.008 & 0.013 \\
\hline
\end{tabular}

The base material microstructure is presented in Figure 1 and consists of $73 \pm 3 \%$ ferrite matrix and other constituents such as martensite, bainite and retained austenite.

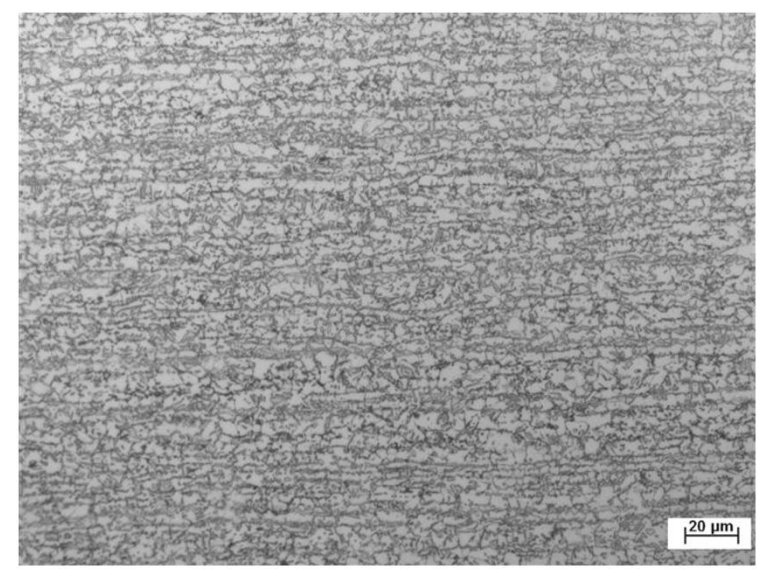

Figure 1. Base material microstructure. 
The welds were realized in a fiber laser workstation doted of an IPG YLR-2000 laser, with maximum power $2000 \mathrm{~W}$, minimum spot of $0.1 \mathrm{~mm}$ and almost Gaussian intensity profile. The moving in three axis were coordinated by a CNC table. Figure 2a presents a schematic picture of the current laser workstation.
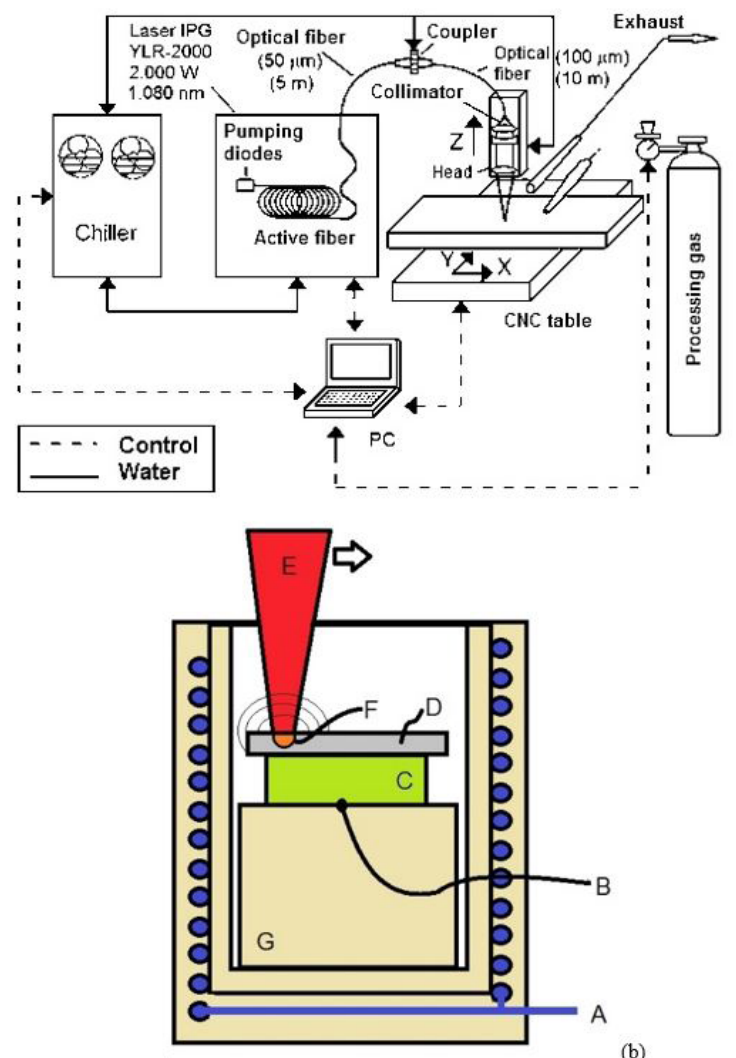

(a)

(b)

Figure 2. Schematics of (a) the laser workstation and (b) the furnace setup. Legend: (A) heating coil; (B) thermocouple; (C) base steel; (D) sample; (E) laser beam; (F) melt pool; (G) alumina block.

Under the CNC table an induction furnace was constructed that heats the sample at a given predefined temperature, as presented in Figure $2 \mathrm{~b}$. In the figure, an inductive heating coil (A) induces heat into the sample material (D) as well as to the base steel (C). The temperature was recorded by a K-type thermocouple fixed at the bottom of the base steel (C). An alumina brick (G) has been used to support the sample into the right focusing position. Once the right temperature is reached a laser beam $(E)$ produce a weld $(F)$ in the sample (D).

The sample is heated at $0.24^{\circ} \mathrm{C} / \mathrm{s}$ up to $500^{\circ} \mathrm{C}$ and a single weld run was realized in the middle of the coupon. After welding, the sample is kept at $500{ }^{\circ} \mathrm{C}$ per 10 minutes and then slow cooling $\left(0.19{ }^{\circ} \mathrm{C} / \mathrm{s}\right)$ cooled down to ambient temperature. These coupons were called HT (high-temperature) welds thereafter.

As the temperature evolution and related thermal gradients are difficult to measure during laser welding, a finite element method program (ESI-Group Sysweld [9]) was used to determine the temperatures during laser interaction. The physical-chemical database for simulation is that the TRIP 750 alloy. In order to validate the calculated results, some preliminary welds were carried out, specifically to evaluate the absorptivity of the laser raditation.

For comparison purposes, ambient temperature (AT) and traditional tempered welds (TW) were also produced. TW route was $500^{\circ} \mathrm{C} / 10$ minutes in a tubular furnace under ambient atmosphere.

For the time-temperature-transformation (TTT) plot of the TRIP 750 steel a University of Cambridge proprietary software called MUCG83 had been used [10]. The software was conceived after Professor Bhadeshia long experience in phase transformation of ferrous alloys [11,12]. 
Light optical microscopy (LOM) and scanning electron microscopy (SEM) were realized by a Zeiss Imager2M and Hitachi TM-3000 microscopes, respectively. The polished surfaces, using standard polishing procedure, were etched by Nital $2 \%$, i.e. $2 \%$ nitric acid in ethanol.

Hardness measurements were carried out using a FutureTech FM-700 Vickers microhardeness tester. The load was $100 \mathrm{gf}$ and dwell time was 10 seconds. The hardness profile was measured at the middle of the upper sheet.

Erichsen cupping tests were performed according to ISO 20482 standard [13]. A $7.9 \mathrm{~mm}$ radius tool steel sphere was pressed against a $38 \mathrm{~mm}$ diameter coupon of laser welded TRIP sheet using an EMIC 10.000 universal tensile/compressive test machine. The load was applied to a maximum of the sphere diameter or until the break of the cup using a compressive rate of $5 \mathrm{~mm} / \mathrm{min}$. The contact area between the sphere and the coupons was estimated according to the contact mechanics fundamentals [14].

\section{Results and Discussion}

\subsection{Transformation kinetics}

Figure 3 presents the TTT diagram plotted together with measured and calculated temperature profiles. The transformation boundaries for ferrite start (F), bainite start (B) and martensite start (Ms) were plotted for the $1 \%$ phase transformation, accordingly to Bhadeshia formalism [10]. The estimated temperature range for Widmanstatten start are between 660 and $700{ }^{\circ} \mathrm{C}$, the nucleation limited bainite start temperature is $552^{\circ} \mathrm{C}$, which is in good agreement with the literature [15], and the martensite start temperature is $403^{\circ} \mathrm{C}$ for the current alloy [10].

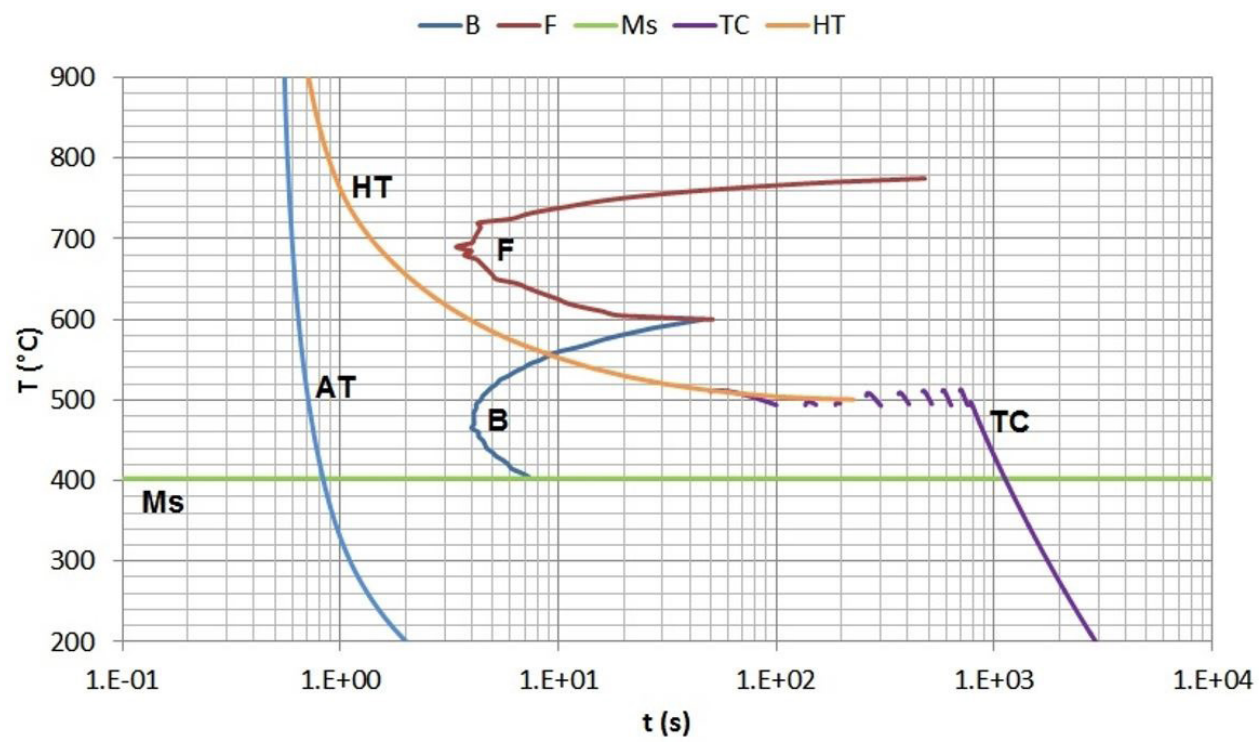

Figure 3. TTT plot together with calculated and measured temperature profiles. Legend: $B=$ bainite start; $F=f e r r i t e$ start; $\mathrm{Ms}=$ martensite start; $\mathrm{TC}=$ thermocouple measurements; $\mathrm{HT}=$ high-temperature weld; $\mathrm{AT}=\mathrm{ambient}$ temperature weld.

The FEM calculated temperature profiles for ambient temperature weld (AT) and high temperature weld (HT) conditions are plotted in Figure 3. The temperatures were obtained for FEM simulations at a point in the middle of the fusion zone. The thermocouple data (TC) are plotted to complete the temperature evolution at HT. The estimated cooling rate when AT crosses $\mathrm{Ms}$ is $640^{\circ} \mathrm{C} / \mathrm{s}$, which is sufficient to harden the entire FZ. The HT curve crosses the bainite domain in a temperature of $553^{\circ} \mathrm{C}$, which is projected for nucleation of bainitic ferrite. The overall austempering period was about 1'000 seconds. According to TC data, the cooling rate of TC curve near to $\mathrm{Ms}$ is $0.19^{\circ} \mathrm{C} / \mathrm{s}$. 
Considering the temperatures evolutions and the projected TTT as presented in Figure 3 , it is expected fully martensite grains for AT and partial bainitic grains in HT case. A fully bainitic grain is unlike to occur due to the segregation of face-centered cubic stabilizing elements and the strains generating ahead of the bainitic ferrite. Many models had been proposed to predict bainite volume fraction in steels in different times and temperatures [12]. However, the applicability of these models to the current case is limited because of rapid solidification microstructures, which implies in different elements distribution and strains in the grains. These models have been successfully applied to annealed and relatively large grains, with low strain levels, and subject to isothermal temperatures below Bs.

Here, both austenitizing (e.g. Mn) and ferritizing (e.g. Si) elements segregate into the interdendritic space. The alloy partition coefficient in equilibrium of three important elements $\mathrm{C}, \mathrm{Si}$ and $\mathrm{Mn}$ are $0.5533,0.6933$ and 0.7197 , respectively [16]. At $50 \mathrm{~mm} / \mathrm{s}$ welding speed, very little solute trapping occurs and intermetallics, or even carbides, may form in the interdendritic region. On the one hand, microsegration may result in the displacement of the ferrite curve to the left of Figure 3. In this case, it is important to keep the isotherm as low as possible, although above the Ms line. On the other hand, bainite nucleation and consequently its growth may be also influenced by these modulations [12].

\subsection{Microstructure}

\subsubsection{Ambient Temperature welds (AT)}

Figure 4 presents light optical microscope images of the AT welds. Figure 4a shows the different regions: FZ: fusion zone, HAZ: heat-affected zone and BM: base material. The width of the weld at the top is $0.83 \mathrm{~mm}$ and the extension of the HAZ varies from 0.10 to $0.16 \mathrm{~mm}$, depending on the depth. The fusion depth is $2.0 \mathrm{~mm}$ and extends below the interface (I) between the sheets. Figure $4 \mathrm{~b}$ shows the grain structure in the $\mathrm{FZ}$ as composed of martensite laths with an average width of $0.8 \mu \mathrm{m}$. Figure $4 \mathrm{c}$ shows the HAZ bounded by FZ and BM at right and left. It is clear that this region heats exceeding the austenitization temperature and generates a fine martenstic array. Together with the LOM image, in detail, the SEM micrograph reveals martensite needles and some untransformed ferrite (rounded particles). At the left of Figure 4c, the base material (BM) presents a slightly high martensite content (gray phase) compared to the base material far from the weld line (Figure 1), as a result of the fuzzy boundary between FZ and HAZ.

\subsubsection{Tempered Welds (TW)}

The tempered welds are those subject to weld at ambient temperature followed by tempering at $500{ }^{\circ} \mathrm{C}$ per 10 minutes. The TW shape is the same of AT welds, when comparing Figure 4a to Figure $5 \mathrm{a}$, but the etched contrast is lighter for TW since ferrite is less etched by Nital than martensite. The FZ microstructure is marked by allotriomorphic ferrite, as presented in Figure 5b. The SEM micrograph (detail in Figure 5b) indicates that the as-welded microstructures were not homogenized by tempering and then two types of ferrite appeared: allotromorphic and polygonal, with some coalescence where the dendrite tips converged. The HAZ, Figure 5c, presents similarities to the AT HAZ (Figure 4c) although the secondary transformation of the austenite grains develops equiaxed ferrite with some rounded carbides for TW.

\subsubsection{High-Temperature welds (HT)}

HT welds had a macrostructure similar to AT and TW, Figure 6a, but were marked by bainitic grains, as presented in Figure $6 \mathrm{~b}$. The carbide pattern is not visible in the SEM, Figure $6 c$, and thus it is not possible to classify in upper or lower bainite types. The HAZ is a mixture of the initial ferritic grains and bainitic ferrite decorated austenite grains, as presented in Figure $6 \mathrm{~d}$. The base material after austempering (Figure 6a) is similar to the base material in as received condition (Figure 1).

\subsection{Hardness}

Figure 7 shows the hardness profile as a function of the distance from the weld centerline (CL). The base material hardness, around $200 \mathrm{HV}$, did not change for the different routes (AT, TW or HT) and corroborates the microscopic observation of an unchanged base material. The AT hardness in the fusion zone attained around $450 \mathrm{HV}$, which is pertinent to the hardening due to the martensitic transformation [2]. When the AT welds were 

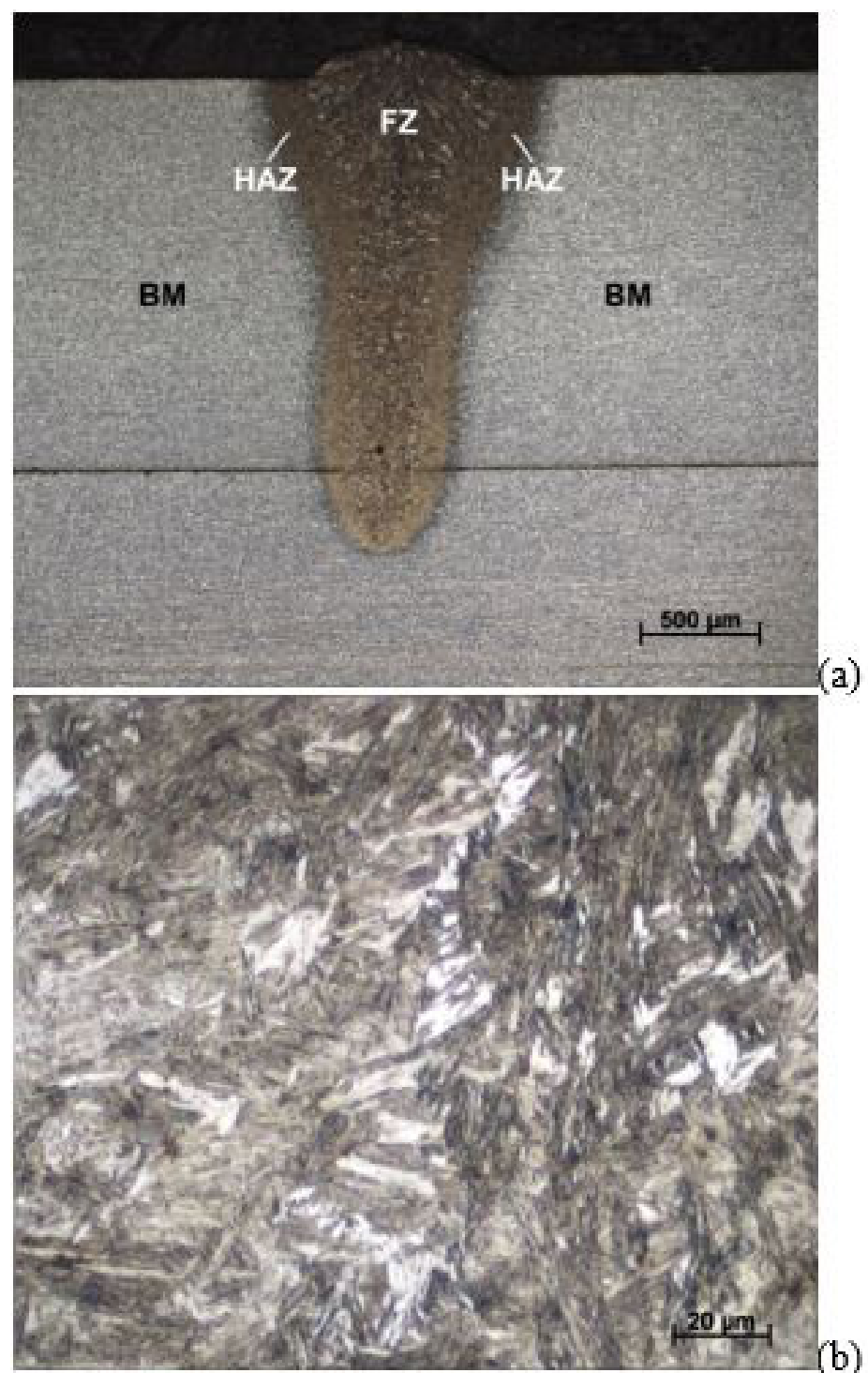

a)

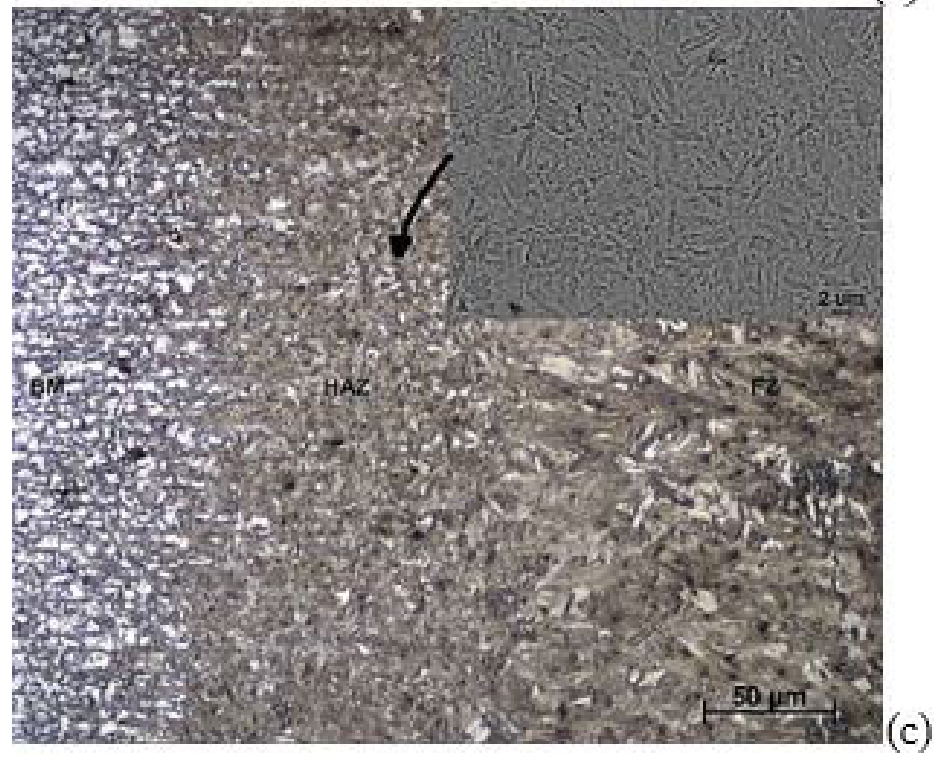

Figure 4. Micrographs of AT welds: (a) general view (LOM); (b) FZ (LOM); and (c) HAZ (LOM and SEM). 

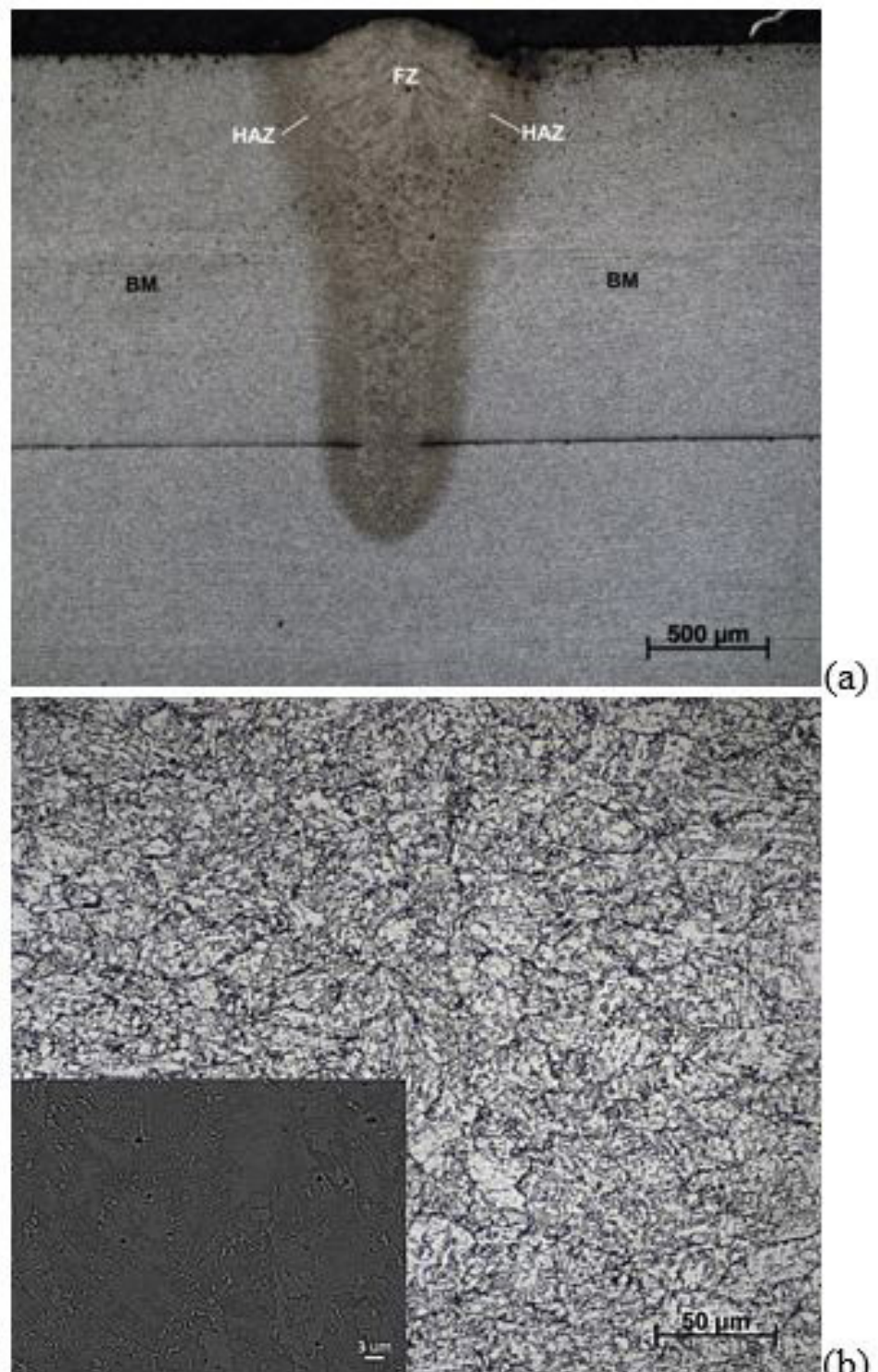

(a)

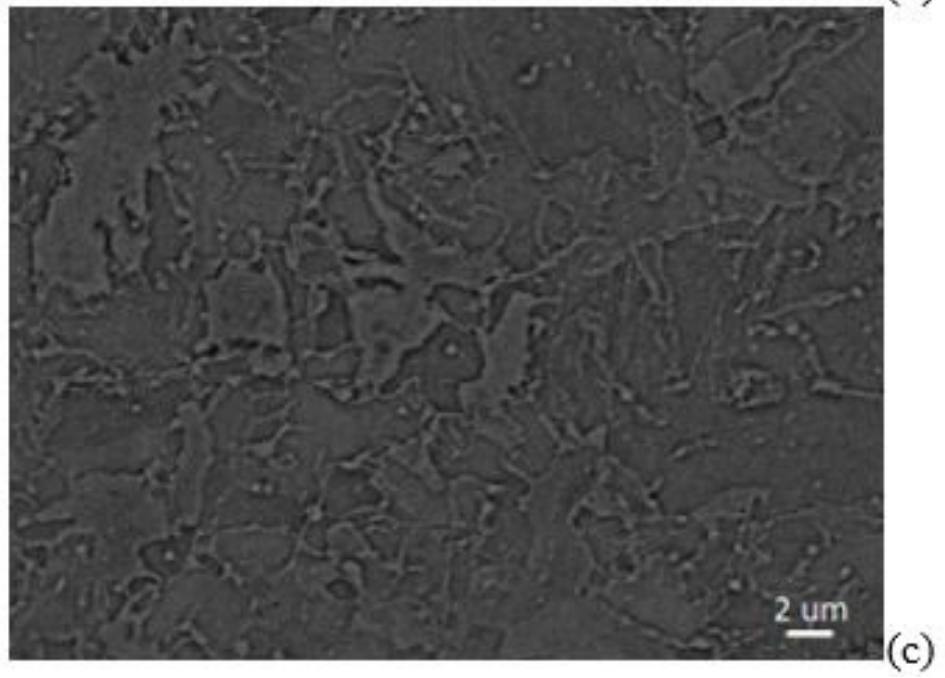

Figure 5. Microstructure of the TWs: (a) general view of the weld near to the top; (b) Microstructure in the center of FZ, LOM and SEM; (c) SEM image in ZTA. 

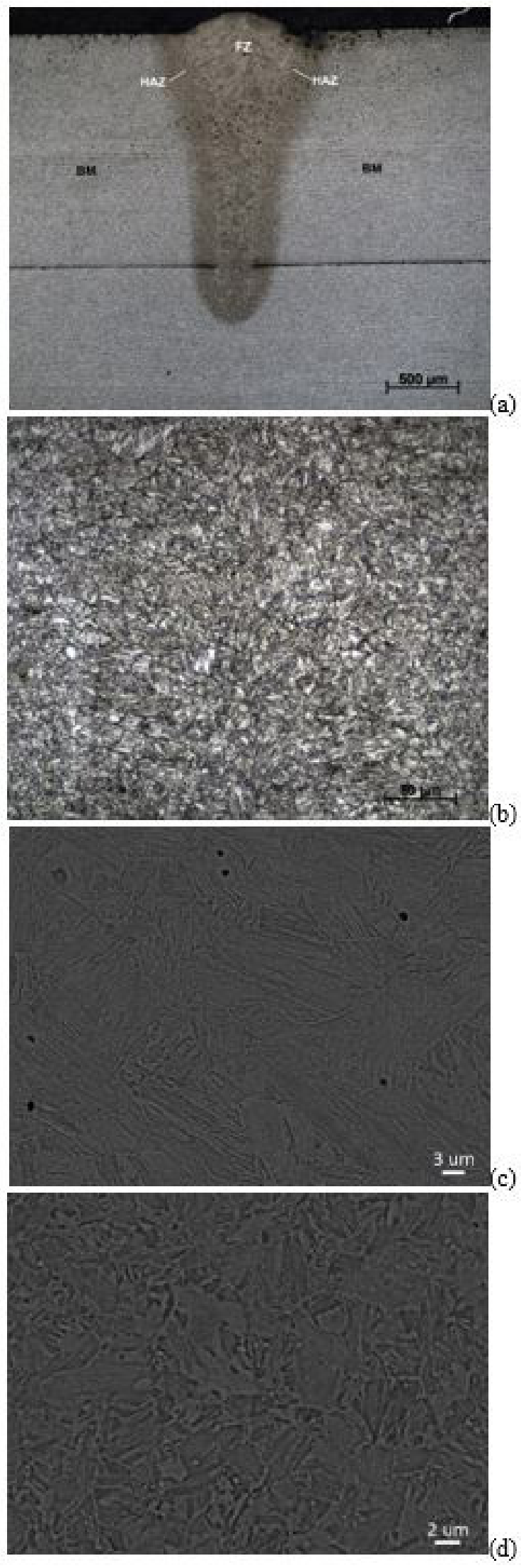

Figure 6. Microstructure of HT welds: (a) macrography; (b) LOM in FZ; (c) SEM in FZ; (d) SEM in HAZ. 


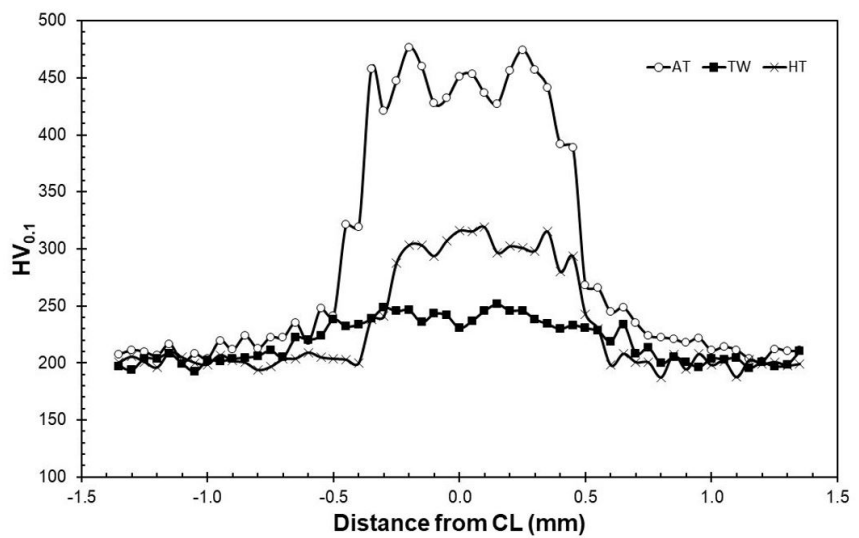

Figure 7. Hardness profile of AT, TW and HT type welds plotted as a function of the centerline distance.

annealed at $500{ }^{\circ} \mathrm{C}$ per 10 minutes, the hardness is greatly reduced to $230 \mathrm{HV}$, which is slightly above to the base material. The austempered weld (HT) presents a maximum hardness value in $\mathrm{FZ}$ of $300 \mathrm{HV}$, being intermediary between AT and TW, and characterizing the bainite transformation [5].

\subsection{Erichsen}

Figure 8a presents the compressive stress versus displacement for three coupons, representative for the AT, TW and HT conditions. As can be seen, the elastic part of the curve is similar in any conditions and the yield point is approximately $110 \mathrm{MPa}$. This value is $1 / 4$ of the yield strength during tensile mechanical tests [5] because of the very localized strained region. After the elastic region, the stress dropped to about $100 \mathrm{MPa}$ due to the plastic deformation of the entire cup and then, after about $2.4 \mathrm{~mm}$, the curves rise again due to the TRIP effect. The maximum stress was about 200, 170 and $165 \mathrm{MPa}$, for the AT, TW and HT coupons respectively.
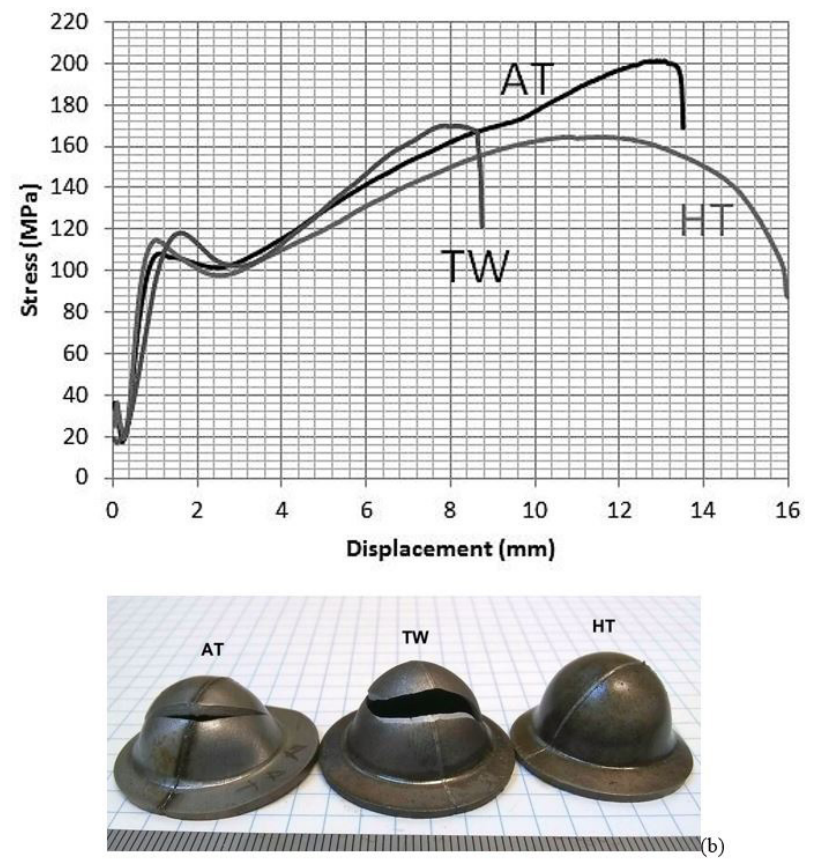

(a)

Figure 8. Erichsen cupping test for AT (ambient temperature), TW (tempered weld) and HT (high temperature) coupons: (a) measured stresses versus the depth of the indentation during the test; (b) the final aspect of the coupons at the end of the test. Lower scale in millimeters. 
Ambient temperature samples possess a hardened track in the middle of the coupon and thus the weld behaves as a hard beam. Therefore, for the AT condition, the premature break and higher compressive strength could be explained in terms of martensite transformation.

The tempered weld (TW) condition also failed before the end of the test because of the softening due to the ferrite development and spherodization of the carbides. In this case, the unbalanced tempered structure (Figure $5 b$ ) produced premature plastic flow of the grains leading to necking. The measured welds reductions in thickness (striction) after the cup test were $1.1 \pm 0.3 \mathrm{~mm}, 0.8 \pm 0.3 \mathrm{~mm}$ and $0.8 \pm 0.3 \mathrm{~mm}$, for AT, TW and HT, respectively. These results shown the TW striction was similar to the $H T$, although the final displacement was $8.5 \mathrm{~mm}$ compared to $16 \mathrm{~mm}$ of AT. Consequently, the localized reduction in the weld area, due to softening, could be verified for the TW coupon.

For HT, the weld material is more homogeneous and the plastic curve height is reduced. The HT coupon resisted up to $16 \mathrm{~mm}$ displacement, where the test is interrupted. Figure $8 \mathrm{~b}$ presents the final aspect of the cups at the end of the tests with HT condition presenting more deep drawing than the others and absence of cracking.

It is difficult to compare the Erichsen test results with the literature because the conventional test only evaluates the punch rise at constant speed. Han et al. [17] studied Erichsen cup height of TRIP 800 steel with a punch rising speed of $7 \mathrm{~m} / \mathrm{min}$. The maximum height obtained by the authors was $6.5 \mathrm{~mm}$, which is well below the current results, as Figure $8 \mathrm{a}$. The authors associated the low forming height to the porosity level in the weld beads, not present in the present investigation.

\section{Conclusions}

The present paper compared laser welded TRIP 750 steels produced at ambient temperature (AT), after tempering (TW) at $500^{\circ} \mathrm{C} / 10$ minutes and austempered (HT) at the same time and temperature. After the results, the following conclusions could be drawn:

AT welds were characterized by an almost fully martensitic structure, with average hardness about $450 \mathrm{HV}$.

TW welds presented tempered martensite in the fusion zone (FZ) with a hardness similar to the base material (230 HV).

HT welds shown intermediate hardness (300 HV) and a typical bainitic microconstituent.

Erichsen cup test for the HT condition presented high formability compared to the TW and AT conditions, because of the premature fail during drawing of these later. The reasons for premature breakage were associated to martensite (AW) and softening (TW).

Consequently, for the current conditions, high temperature welded coupons are promising for cold forming operations.

\section{Acknowledgements}

This research has been funded by Fundação de Amparo à Pesquisa do Estado de São Paulo (FAPESP) under grant \# 2016/16683-8. Thanks are also due to Mrs Caroline Cristine de Andrade Ferreira and Mr Caue Pettermann Carvalho for technical support.

\section{References}

[1] Saunders FI, Wagoner H. Forming of tailor-welded blanks. Metallurgical and Materials Transactions A, Physical Metallurgy and Materials Science. 1996;27(9):2605-2616. http://dx.doi. org/10.1007/BF02652354.

[2] Mujica L, Weber S, Pinto H, Thomy C, Vollertsen F. Microstructure and mechanical properties of laser-welded joints of TWIP and TRIP steels. Materials Science and Engineering A. 2010;527(78):2071-2078. http://dx.doi.org/10.1016/j.msea.2009.11.050.

[3] Mujica L, Weber S, Thomy C, Vollertsen F. Microstructure and mechanical properties of laser welded austenitic high manganese steels. Science and Technology of Welding and Joining. 2013;14(6):517-522. http://dx.doi.org/10.1179/136217109X434243.

[4] López Cortéz VH, Pérez Medina GY, Reyes Valdéz FA, López $H F$. Effects of the heat input in the mechanical integrity of the welding joints welded by GMAW and LBW process in Transformation Induced Plasticity steel (TRIP) used in the automotive industry. Soldagem e Inspeção. 2010;15(3):234241. http://dx.doi.org/10.1590/S0104-92242010000300010.

[5] Correard GCC, Miranda GP, Lima MSF. Development of laser beam welding of advanced high-strength steels. International 
Journal of Advanced Manufacturing Technology. 2016;83(912):1967-1977. http://dx.doi.org/10.1007/s00170-015-7701-2.

[6] Allain S, Perlade A. Modern bainitic steels for automotive applications. In: Proceedings of Bainite Workshop; 2012 May 16; La Défense, Paris, France. Madrid: CSIC; 2012.

[7] Lima MSF, Gonzales D, Liu S. Microstructure and mechanical behavior of induction-assisted laser welded AHS steels. Welding Journal. 2017;96(10):376S-388S.

[8] Ahmed E, Reisgen U, Schleser M, Mokrov O. On formability of tailor laser welded blanks of DP/TRIP steel sheets. Science and Technology of Welding and Joining. 2013;15(5):337-342. http://dx.doi.org/10.1179/136217110X12731414739754.

[9] ESI-GROUP [internet page]. Paris: ESI Group Headquarters; 2018. [access 4 june 2018]. Available from: https://www. esi-group.com/software-solutions/virtual-manufacturing/ welding-assembly-simulation

[10] Materials Algorithms Project Program Library [internet page]. Cambridge: University of Cambridge; 2018. [access 4 june 2018]. Available from: https://www.phase-trans.msm.cam. ac.uk/map/steel/programs/mucg83.html
[11] Bhadeshia HKDH. A thermodynamic analysis of isothermal transformation diagrams. Metal Science. 1982;16(3):159-165. http://dx.doi.org/10.1179/030634582790427217.

[12] Bhadeshia HKDH. Bainite in steels: transformations, microstructure and properties. London: IOM Communications; 2001.

[13] International Organization for Standardization - ISO. ISO 20482:2003(E): metallic materials: sheet and strip: erichsen cupping test. Geneva: ISO; 2003. 12 p.

[14] Wikipedia. Contact mechanics. 2018. [access 4 june 2018]. Available from: https://en.wikipedia.org/wiki/Contact_mechanics

[15] Lee YK. Empirical formula of isothermal bainite start temperature of steels. Journal of Materials Science Letters. 2002;21(16):12531255. http://dx.doi.org/10.1023/A:1016555119230.

[16] Andersson JO, Helander T, Höglund L, Shi PF, Sundman B. Thermo-Calc and Dictra, computational tools for materials science. Calphad. 2002;26(2):273-312. http://dx.doi.org/10.1016/ S0364-5916(02)00037-8.

[17] Han T-K, Park SS, Kim K-H, Kang C-Y, Woo I-S, Lee J-B. $\mathrm{CO}_{2}$ laser welding characteristics of $800 \mathrm{MPa}$ class TRIP steel. ISIJ International. 2005;45(1):60-65. http://dx.doi.org/10.2355/ isijinternational.45.60. 